\title{
マルチプローブによる物質構造の研究
}

\author{
高エネルギー加速器研究機構物質構造科学研究所 瀬戸秀紀
}

\section{Hideki SETO: Multi-probe Experiments to Investigate Material Structures}

"Multi-probe" is a general way to investigate unknown properties of materials experimentally. In cases of material structures, various kinds of methods such as X-ray Scattering, Neutron Scattering, Electron Microscopy, Nuclear Magnetic Resonance, have been used. In these methods, Synchrotron Radiation, Free Electron Laser, Neutron, Muon and Slow Positron have common properties; these beams are supplied at large accelerator facilities, and are utilized under similar user programs. Therefore, it is an international trend to prepare common platform for the multi-probe use in order to maximize scientific output. Here we collect several examples of multi-probe studies in various fields to know how the multi-probe investigation is effective.

\section{1. はじめに}

「群盲象を評す」という言葉がある。これは数人の盲人 が象の一部だけを触って感想を言い合うが, 触った部位 により感想が異なり対立する, という寓話である。「巨人 の肩の上に乗る」科学研究においてはこの寓話ほどの見 当外れの解釈が出てくることはないが, しかしながら未 知の現象に出会ったときにはさまざまな手法を用いて実 験事実を積み重ね, それらを総合することによってその 現象の「真の姿」を明らかにしていくこと, すなわち複 数の「プローブ」を用いて実験を行うということは科学 研究の本質である。そして結晶構造の研究に限っても, 世界中の研究者が何十年も前から，X線や中性子のみな らず電子顕微鏡や NMRなどの複数のプローブを相補的 に用いることによってその本質を明らかにしようとして きた。

その中で, 特に大型施設で供給されるいわゆる量子 ビームを用いた研究を「マルチプローブの相補的利用」 と称するようになったのは, ここ10年ぐらいのことでは ないだろうか. これまでは大型施設がそれぞれで申請書 を受け取り, 審査し, ビームタイムを割り当て, 実験を 実施するという流れだったが，そのようなプロセスを各 施設が独立に行うよりもある程度共通化して効率を上げ るべきではないか, そしてそれによって研究成果も最大 化できるのではないか，という問題意識がユーザー側か らも施設側からも出てきている, というのがその理由で あろう。とりわけ加速器から発生する放射光や自由電子 レーザー, 中性子, ミュオン, 陽電子は, いずれも構造 研究にとって有効かつ相補的なツールであるのと同時に 施設の運営形態も似ていて, 課題審査や運営を共通化 することに関するメリットは大きい.
大型施設をシームレスに使えるようにしようという 流れは, 海外においてはすでに当然のものと思われるよ うになっている。例えばフランスのグルノーブルには 同じキャンパスの中に放射光施設 ESRF と中性子実験用 の研究用原子炉ILLがあり, 宿舎やレストランなどのイ ンフラを共通で使うようになっていてユーザーは2つの 施設を自由に行き来することができる，イギリスでは中 性子とミュオンの研究拠点として 50 年近い歴史のある Rutherford Appleton研究所と同じキャンパスにDiamond Light Sourceを建設し，2007年から利用を開始した。こ のキャンパス内には中央レーザー研究所を始めさまざま な大型施設が集合して, まさに「マルチプローブ研究セ ンター」の様相を呈している. 中性子、ミュオン施設と 放射光施設が隣同士に設置されているのはスイスの Paul Scherrer研究所も同様で, 1980年代から利用されている 中性子施設の SINQ, ミュオン施設の S $\mu$ S に加えて 2001 年にSwiss Light Sourceが建設され, 加えてXFEL施設も 建設中である。さらにスウェーデンでは, 次世代の放射 光源MAX IVと中性子源ESS 同じキャンパス内に作 ろうとしている.

一方オーストラリアでは, 地理的に離れている2つの 施設 (放射光施設 AS と中性子施設 OPAL) を 1 つの研究 所が運営する, ということを始めている。ちなみにアメ リカでは放射光施設を中性子・ミュオン施設と同じキャ ンパス内に置いているところはないものの, 中性子の課 題が採択されると放射光のビームタイムが付いてくる例 がある,とも聞いている。

わが国においては各大型施設の成り立ちも予算ソース も違い, また背負っている歴史も違うので統合は簡単で はないが, マルチプローブ利用を促進しようという試み はスタートしつつある。例えばPFと J-PARCをもつ KEK 
物構研は, この春から放射光・中性子・ミュオン・低速 陽電子を複数利用する課題である「マルチプローブ課 題」の公募を開始する。またJASRI と CROSS は SPring-8 と J-PARCの相補利用を促進するための方策を模索中で ある、いずれにしろ国内に扔いても何らかの形で「共通 プラットフォーム化」していく必要があるというのは, 施設側もユーザーも含めた共通認識になっていると言 える，そのためには行政を巻き込んだ制度設計も必要だ が，それと同時にマルチプローブを用いた研究の実績を 積み重ねて，それによってマルチプローブ利用研究の重 要性を示していくことが必要なのではないだろうか.

\section{2. 本特集の概要}

今回の特集では, 結晶から高分子や生体物質に至るさ まざまな系について, それぞれの分野の代表的な研究者 によりそれぞれの「マルチプローブ研究」を紹介してい ただいた。これらの記事は内容的に, 構造物性分野, 材 料科学分野, 生命科学分野の 3 つに分けることができる.

最初は構造物性分野の研究例である. 山浦らによる $\lceil\mathrm{X}$ 線, 中性子, ミュオンを用いた鉄系超伝導体の研究」 では, 高濃度電子ドーピングを行った鉄系超伝導体で 発見された $2 つ の$ 超伝導相の出現要因を, 3 種類の量子 ビームを用いて明らかにしようとした研究を紹介して いる.この研究では最初にミュオンを用いて磁気秩序に ついて網羅的に調べ, 続いて中性子回折により磁気構造 を決定している。 そして磁気秩序形成に関連する構造転 移の詳細を放射光実験により明らかにした. 3 種類のプ ローブの特徴を活かして超伝導相と磁気秩序の関係を

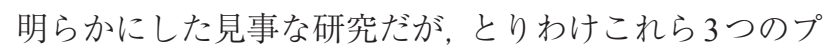
ローブによる協奏的研究を推進するKEK構造物性研究 センターという受け皿があったからこそ成立した研究 である，とまとめている。この研究を推進する「元素戦 略プロジェクト」のような世界的な競争の激しい分野で は, マルチプローブ実験をタイムリーに行うことが重要 であることを示す好例であろう。

これに続くのは八島による「中性子とX線回折法を含 む多面的アプローチによるセラミック材料の結晶構造, 電子密度分布とイオン拡散経路の研究」という記事であ る.この中では光触媒や鉛フリーの誘電体, イオン伝導 体, 燃料電池などの実用材料に応用可能なセラミック材 料の構造解析を, X線と中性子だけでなく電子線回折や 密度沉関数理論計算なども含めたさまざまな手法を併 用することによって精密化した例を紹介している. 単結 晶が手に入りにくい材料の構造決定のためには粉末回折 データから未知構造解析を行う必要があるが, そのため にそれぞれの手法の利点と制限をよく理解して, 多面的 な構造解析を行うことの重要性が強調されている。

石井と藤田の連名による記事は「軟X線・硬X線・中
性子非弾性散乱を用いた銅酸化物超伝導体のダイナミク ス研究」というタイトルである. 銅酸化物超伝導体の超 伝導発現機構を明らかにするためには, 電子状態とその 相互作用を知る必要があるが, そのためには $0.1 \mathrm{eV}$ 程度 のエネルギー領域のダイナミクスを調べなければなら ない. 数年前までは非弾性 X線散乱も非弾性中性子散乱 も苦手としていたエネルギー領域であったが, 近年の実 験技術の発展によって可能になってきた。これまで価電 子を観るという点での X線と中性子の相補利用は静的 構造に限られていたが, 非弾性散乱による動的構造の研 究においてもそれが可能になってきた，ということを紹 介している。

材料科学分野に㧍ける研究例では, 高分子, 水素貯蔵 合金, 触媒を取り上げている. 金谷らによる「SANS と SAXSを利用した流動と変形による高分子結晶化研究」 では, 高弾性率・高強度の高分子材料を作るために必 要な「シシケバブ構造」の形成機構を明らかにするため に, 中性子とX線の小角散乱を併用した結果を示してい る. 高分子のようなソフトマターは一般的に原子スケー ルからマクロスケールに至る階層的構造を取っており, 1つの実験方法だけでその全容を明らかにすることはで きない. その上シシケバブ構造形成に関しては, 分子量 や分子量分布, 結晶化温度や流動の加え方などのさまざ まな要因が絡んでいて複雑である. また構造の違う領域 が空間的に分布しているため, ビームを絞って場所ごと の構造の違いを調べることも重要である。したがって中 性子とX線のみならず, 光学顕微鏡や光散乱なども含め たマルチプローブによる研究は必須であり, 今後さらに 盛んになることは疑いがない，と結んでいる。

続いて町田による「X線抢よび中性子を用いた水素一 金属系の構造研究」では, 水素吸蔵合金であるランタン 2水素化物の高圧力下での相分離現象と, それに伴う新 規構造水素化物の形成の発見を例にして, X線回折と中 性子回折の相補的利用がいかに有効か, という点につい て詳述している. 金属原子の散乱能が高く, 高精度の実 験が可能な放射光X線は金属副格子の構造決定に適し ている. また微量の試料でも測定可能なので, 高圧実験 でも短時間測定が可能であり広い範囲での構造のサー ベイが可能である, 一方中性子を用いることにより, 水 素原子の金属格子中の位置や占有率を知ることができ る。これらの情報を複合的に用いれば, 水素吸蔵によっ てどのような結晶格子の破壊や乱れが生じるか, これら による格子久陥が水素貯蔵能にどのように影響するか, などの情報を得ることもできる。近未来のエネルギー戦 略のキーワードとして知られる「水素社会」を実現する ためには, 水素と物質の相関について媣く知る必要が ある，そのためにX線と中性子の相補利用がきわめて有 効であることはこの研究例から見ても明らかであり, 基 
礎科学のみならず実用材料も含めた大きな展開が期待 できる。

次の有賀と朝倉による「Rutile型 $\mathrm{TiO}_{2}$ のナノ構造と物 性一ポス卜結晶構造解析」という記事では, 触媒材料と して注目されている $\mathrm{TiO}_{2}$ の研究を紹介している。この物 質は表面構造や欠陥構造によって触媒作用が大きく変 わることが知られている，固体表面の構造を調べる実験 手法はいろいろあるが, この研究では特に陽電子, ミュ オン, 放射光という 3 種類の量子ビームを相補的に用い ている. 物質の構造解析には回折法が有効であることは 論を待たないが，欠陥や不純物などを含む系は必ずしも 長距離秩序をもたないため実験的に難しい。そのような 場合に三次元的な繰り返しを必要としないこれらの手 法が有効であることから, 「回折法・顕微法に加わる第 3 の構造解析法になると期待される」と結んでいる. 量子 ビームによるマルチプローブ研究の新たな可能性を示す ものとして，きわめて興味深い解説記事となっている.

生命科学関係の記事は4つ。まず湯本と千田による 「創薬等支援技術基盤プラットフォームで取り組む相関 構造解析」では, 構造生物学の新たな発展について紹介 している。これまで構造生物学の主な目的はタンパク質 の立体構造の決定だったが, 構造決定に留まらずさまざ まな手法を併用することで, 生命現象をより多面的に捉 え理解するという「構造生命科学」とも呼ぶべき分野に 発展しつつある。，そのカギとなるのはX線結晶構造解析 とX線小角散乱解析に加えて, 電子顕微鏡と NMR を組 み合わせた「相関構造解析」である。ここで紹介されて いるような, これらの複数の実験手法に生命科学研究者 の誰もが簡単にアクセスできるという環境は今のところ は「創薬等の支援」を目的としているものだけだが，あ らゆる「マルチプローブ利用研究」の将来像として捉え るべきではないか，と思われる。

有田による「相関構造生物学による UHRF1 のヒスト ン認識機構の解明」では, 真核生物のDNAがヒストン 8 量体に巻き付いて形成されるクロマチン構造を制御す るタンパク質であるUHRF1の機能と構造を，X線結晶 構造解析 (PX), X線小角散乱 (SAXS) と NMR 用いて 相関構造解析を行った, という例を紹介している.PX, SAXS，NMRの各手法の長所と短所を補い合うことによ り, タンパク質同士がどのように相手を認識するのか, その機構を解明することができる. 加えて複合的に構造 生物学的な手法を用いて解析することにより, 新たに見 えてくる情報もある. 複雑な生体分子の構造と機能を明 らかにするためには「マルチプローブ研究」が必須であ る，ということがよくわかる研究紹介となっている。

中村らによる「反転型セルラーゼの巨大結晶作製と中 性子 / X 線共構造解析」では, 糖質加水分解酵素の中性 子とX線を用いた構造解析により，反応メカニズムを明
らかにしようとした研究を紹介している，X線構造解析 は電子を多くもつ炭素, 酸素, 窒素原子などの位置を精

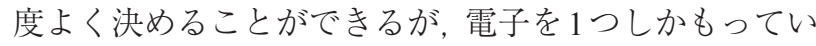
ない水素原子は困難度が高い。一方中性子は原子核に よって散乱されるため，ほかの原子と同様に水素原子の 位置を決定することができる。したがってこれら2つの 手法を併用した構造解析は有用であることは以前より 知られていたが，しかし中性子回折のためには巨大な単 結晶が必要なため実験が困難である, という点がネック だった，そこで筆者らのグループは，さまざまな工夫に より良質な巨大結晶を作製し, 中性子と放射光のマルチ プローブ利用によってしかわからない新しい結果を得て いる，また水素の位置を決めることができただけに留ま らず，放射線損傷が無視できるという中性子の特性を活 かして室温で測定することにより, 凍結状態での構造解 析ではわからなかったことも明らかになった，巨大単結 晶作製は高いハードルだが，中性子回折にはそのハード ルを越えて行うだけの価值がある，ということがよくわ かる解説となっている.

岩崎による「電子顕微鏡技術の進展と相関解析」も 「相関構造生物学」の具体例の 1 つだ゙, こちらは電子顕 微鏡を主軸にした研究を取り上げている. 革命的な技術 の進歩により,X線結晶構造解析法に迫るほどの空間分 解能が得られるようになった生物電子顕微鏡の詳細は, 実験技術の進歩がどのような可能性を広げるのかという 点で興味深い，そしてPX と併用した相関解析技術だけ でなく, 電子顕微鏡と光学顕微鏡の併用による「光 - 電 子相関顕微法」も紹介されており, 大型施設の量子ビー ム利用に限らないマルチプローブ利用研究の例として学 ぶところは多い.

以上, 今回の特集で取り上げた研究例を駆け足で紹 介した、マルチプローブを縦横に利用することによって どのような新しいことが生み出されるのか. これらの解 説を通じて，その一端を感じていただければ幸いである。

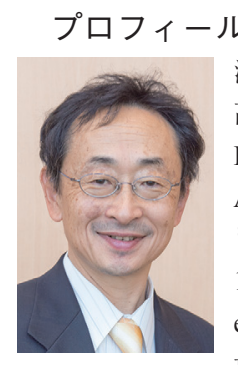

瀬戸秀紀 Hideki SETO

高エネルギー加速器研究機構物質構造科学研究所 Institute of Materials Structure Science, High Energy Accelerator Research Organization 干305-0801つくば市大穂 1-1 1-1 Oho, Tsukuba 305-0801, Japan e-mail: hideki.seto@kek.jp 最終学歴：大阪大学大学院基礎工学研究科博士 後期課程 専門分野：ソフトマター物理 現在の研究テーマ: ソフトマター物理 趣味：スポーツをすることと見ること. かつては野 球とスキー. 最近はテニス, サッカー, マラソン.

日本結晶学会誌 第 57 巻 第 1 号 (2015) 